\author{
Abstracta Iranica \\ Abstracta Iranica Revue bibliographique pour le domaine irano-aryen \\ Volume 37-38-39 | 2018 \\ Comptes rendus des publications de 2014-2016
}

\title{
Rüdiger Schmitt. Stilistik der altpersischen Inschriften. Versuch einer Annäherung
}

Agnes Korn

\section{(2) OpenEdition \\ 12 Journals}

Electronic version

URL: http://journals.openedition.org/abstractairanica/47394

DOI: 10.4000/abstractairanica.47394

ISBN: 1961-960X

ISSN: 1961-960X

Publisher:

CNRS (UMR 7528 Mondes iraniens et indiens), Éditions de l'IFRI

Electronic reference

Agnes Korn, « Rüdiger Schmitt. Stilistik der altpersischen Inschriften. Versuch einer Annäherung », Abstracta Iranica [Online], Volume 37-38-39 | 2018, document 16, Online since 30 December 2018, connection on 27 September 2020. URL : http://journals.openedition.org/abstractairanica/47394 ; DOI : https://doi.org/10.4000/abstractairanica.47394

This text was automatically generated on 27 September 2020

Tous droits réservés 


\title{
Rüdiger Schmitt. Stilistik der altpersischen Inschriften. Versuch einer Annäherung
}

\author{
Agnes Korn
}

\section{REFERENCES}

Rüdiger Schmitt. Stilistik der altpersischen Inschriften. Versuch einer Annäherung. Vienne: Österreichische Akademie der Wissenschaften, 2016, 126 p. (Sitzungsberichte der phil.hist. Klasse 875 / Veröffentlichungen zur Iranistik 79 / Grammatica Iranica 3).

1 The present work is part of a series of important tools for the study of the Old Persian texts that Rüdiger Schmitt has contributed over the last years. He recently published a dictionary (Wörterbuch der altpersischen Königsinschriften, Wiesbaden, Reichert, 2014 https://reichert-verlag.de/

9783954900176_woerterbuch_der_altpersischen_koenigsinschriften-detail) to go with his edition of the Achaemenid inscriptions (Die altpersischen Inschriften der Achaimeniden. Editio minor mit deutscher Übersetzung, Wiesbaden, Reichert, 2009 https://reichertverlag.de/9783895006852_die_altpersischen_inschriften_der_achaimeniden-detail) and now offers a treatment of figures of speech that he has detected in this corpus.

2 This takes the form of 43 entries or short articles of (mostly) one to three pages devoted to the individual figures of speech in alphabetical order, from Alliteration to Zeugma (a list of these in the table of contents would have been welcome). Each entry begins with a short definition and then presents Old Persian passages where the phenomenon is found. The work rests on the observation that the royal inscriptions, carved in rock, are obviously different from normal prose by their very nature and represent stylistically elaborate texts. The discussion carefully limits itself to the analysis of the Old Persian material without comparing data from other languages, 
giving priority to the interpretation of the texts in question and thus contributing to our understanding of many passages.

3 These are then conveniently listed in an index that concludes the work.

\section{AUTHORS}

\section{AGNES KORN}

CNRS, Mondes iranien et indien, Paris 